ARTICLE

https://doi.org/10.1038/s41467-019-09592-1

\title{
High carbon emissions from thermokarst lakes of Western Siberia
}

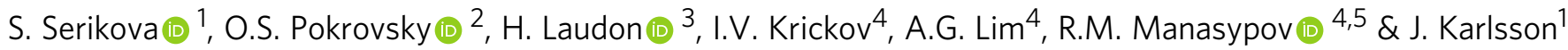

The Western Siberia Lowland (WSL), the world's largest permafrost peatland, is of importance for understanding the high-latitude carbon (C) cycle and its response to climate change. Warming temperatures increase permafrost thaw and production of greenhouse gases. Also, permafrost thaw leads to the formation of lakes which are hotspots for atmospheric $\mathrm{C}$ emissions. Although lakes occupy $\sim 6 \%$ of WSL, lake $C$ emissions from WSL remain poorly quantified. Here we show high $\mathrm{C}$ emissions from lakes across all permafrost zones of WSL. The $\mathrm{C}$ emissions were especially high in shoulder seasons and in colder permafrost-rich regions. The total $\mathrm{C}$ emission from permafrost-affected lakes of WSL equals $\sim 12 \pm 2.6 \mathrm{TgC} \mathrm{yr}^{-1}$ and is 2times greater than region's $C$ export to the Arctic coast. The results show that $C$ emission from WSL lakes is a significant component in the high-latitude $\mathrm{C}$ cycle, but also suggest that $\mathrm{C}$ emission may decrease with warming.

\footnotetext{
${ }^{1}$ Climate Impacts Research Centre (CIRC), Department of Ecology and Environmental Science, Umeå University, Linnaeus väg 6, 90187 Umeå, Sweden. ${ }^{2}$ GET UMR 5563 CNRS, Geoscience and Environment, University of Toulouse, 14 Avenue Edouard Belin, 31400 Toulouse, France. ${ }^{3}$ Department of Forest Ecology and Management, The Swedish University of Agricultural Sciences, Skogsmarksgränd, 90183 Umeå, Sweden. ${ }^{4}$ BIO-GEO-CLIM Laboratory, Tomsk State University, Lenina 36, 634050 Tomsk, Russia. ${ }^{5}$ N. Laverov Federal Center for Integrated Arctic Research, IEPS, Russian Academy of Sciences, Nab. Severnoi Dviny 23, Arkhangelsk 163000, Russia. Correspondence and requests for materials should be addressed to S.S. (email: svetaserikova22@gmail. com) or J.K. (email: jan.p.karlsson@umu.se)
} 
t high-latitudes, temperatures have risen twice as fast as the global average ${ }^{1}$, resulting in widespread permafrost thaw and release of organic carbon (OC) to adjacent waters $^{2}$. Permafrost thaw also leads to the formation of lakes and ponds of various size (hereafter referred to as lakes) that currently cover $\sim 7 \%$ of the permafrost-affected areas ${ }^{3}$ of the Earth. Because of its relatively high lability ${ }^{4}$, OC released from thawing permafrost can be mineralized and emitted from the water surface of lakes in the form of carbon dioxide $\left(\mathrm{CO}_{2}\right)$ and methane $\left(\mathrm{CH}_{4}\right)$, two potent greenhouse gases. Outgassing of both $\mathrm{CO}_{2}$ and $\mathrm{CH}_{4}$ from lakes is of significance to the global carbon (C) cycle ${ }^{5,6}$. Yet quantifying $\mathrm{C}$ emissions from lakes remains challenging, especially in permafrost areas with numerous remote lakes of diverse size.

It has been suggested that climate-induced warming and concurrent permafrost thaw will increase $\mathrm{C}$ emissions ${ }^{5,7}$ from permafrost-affected lakes, mainly as a result of increased terrestrial OC supply and rising water temperatures. . Quantifying C emissions from permafrost-affected lakes is therefore important for providing accurate assessments of the role of climate and permafrost thaw on lake $\mathrm{C}$ evasion, especially at high latitudes, where the most dramatic changes due to warming are under way.

Although measurements of $\mathrm{C}$ emissions from high-latitude lakes have interested scientists for past decades ${ }^{8-11}$, direct measurements of $\mathrm{C}$ emissions from permafrost-affected lakes are rare $^{7}$. Available data suggest that high-latitude lakes, including permafrost-affected lakes, represent a net source of $\mathrm{C}$ into the atmosphere $^{8-11}$ and are recognized as important contributors to regional and global climate ${ }^{12}$. These estimates, however, often do not cover seasonal variability in lake $\mathrm{C}$ emissions, that if neglected could result in major errors in quantifying annual lake $\mathrm{C}$ contribution to atmospheric $\mathrm{C}$ budget $^{8}$. Further, available data on $\mathrm{C}$ emissions from lakes are geographically biased as they have only covered small areas ${ }^{8-11}$, that do not allow assessments of the role of climate and permafrost on lake $\mathrm{C}$ emissions at a larger scale. Such lack of data for annual lake $\mathrm{C}$ emissions across a complete permafrost gradient implies that the role of lakes in permafrostclimate feedback is poorly constrained and can lead to large uncertainties when predicting climate change impacts following permafrost thaw.

The Western Siberia Lowland (WSL), the largest frozen peatland region of the world $\left(\sim 1.3\right.$ million $\left.\mathrm{km}^{2}\right)$ containing $\sim 70 \mathrm{Pg}$ $\mathrm{C}^{13,14}$, is of particular interest for understanding climate-induced changes in the $\mathrm{C}$ cycle at high latitudes. Recent studies stress that permafrost in WSL is vulnerable to thaw ${ }^{15}$ and has been actively degrading over past decades ${ }^{15}$. Lakes represent a common landscape feature in WSL and are formed mainly due to thawing of permafrost ${ }^{16,17}$ (i.e., thermokarst activity). These thermokarst lakes can range in size from small ponds to large lakes, but are typically shallow ${ }^{16,18,19}$ compared to Alaskan ${ }^{9,11}$ and Canadian $^{7,10}$ thermokarst lakes of similar size. Yet, there are only few snapshot measurements of $\mathrm{CO}_{2}$ and $\mathrm{CH}_{4}$ concentrations $s^{5,17,20-22}$ and no estimates of atmospheric $\mathrm{C}$ exchange for lakes across WSL, implying that their role in C cycle is poorly constrained.

In this study, we quantified the atmospheric $\mathrm{C}$ emission $\left(\mathrm{CO}_{2}+\right.$ diffusive $\left.\mathrm{CH}_{4}\right)$ from 76 thermokarst lakes located across a latitudinal gradient from 62 to $67^{\circ} \mathrm{N}$ of WSL. The North-South gradient encompasses major differences in mean annual air temperature (MAAT; from -1 to $-5^{\circ} \mathrm{C}$ ) and permafrost extent (from isolated to continuous permafrost zone). The 76 lakes spanned the size range from 115 to $1,237,000 \mathrm{~m}^{2}$ and were sampled 3 times over the open water season of 2016; after ice-off in spring, in summer and before the development of ice cover in autumn. We measured concentrations and fluxes (using floating chambers) of $\mathrm{CO}_{2}$ and diffusive $\mathrm{CH}_{4}$, and calculated the annual $\mathrm{C}$ emission by multiplying mean daily $\mathrm{C}$ fluxes with the number of ice-free days for each lake.

We find that $\mathrm{C}$ emissions were especially high in shoulder seasons and in colder permafrost-rich regions, and estimate that the total $\mathrm{C}$ emission from WSL lakes is 2-times greater than region's $C$ export to the Arctic coast. Such finding suggests that WSL lakes play an important role in the high-latitude C cycle.

\section{Results}

Seasonal lake C fluxes. $85 \%$ of all studied lakes across different permafrost zones of WSL (Fig. 1) were supersaturated in $p \mathrm{CO}_{2}$ (1044 \pm 554 ppmv, mean \pm interquartile range, IQR) and all lakes were supersaturated in $p \mathrm{CH}_{4}(20.4 \pm 21.8 \mathrm{ppmv})$ (Supplementary Table 1). The $\mathrm{CO}_{2}$ fluxes varied among the permafrost zones (1.7 $\pm 1.7 \mathrm{~g} \mathrm{C} \mathrm{m}^{-2} \mathrm{~d}^{-1}$ ) and showed strong seasonal differences in all zones, whereas diffusive $\mathrm{CH}_{4}$ fluxes $\left(0.2 \pm 0.2 \mathrm{~g} \mathrm{C} \mathrm{m}^{-2} \mathrm{~d}^{-1}\right)$ did vary among the seasons only in the continuous permafrost zone (Fig. 2, Supplementary Tables 1-3). Overall, the C fluxes were dominated by $\mathrm{CO}_{2}$, which constituted on average $88( \pm 12) \%$ of total $\mathrm{C}$ flux across seasons. However, we only estimated diffusive $\mathrm{CH}_{4}$ fluxes, and not ebullition that can exceed diffusive $\mathrm{CH}_{4}$ fluxes by up to 3 -fold in thermokarst lakes ${ }^{5,22}$ and therefore can raise the overall contribution of $\mathrm{CH}_{4}$ fluxes to the total $\mathrm{C}$ flux. Also, considering the $\sim 30$-fold stronger global warming potential of $\mathrm{CH}_{4}$ vs. $\mathrm{CO}_{2}\left(\mathrm{GWP}_{100}=28\right)^{2,23}$ the $\mathrm{C}$ flux expressed in $\mathrm{CO}_{2}$ equivalents from WSL lakes can increase on average 15-times, further emphasizing the importance of lake feedback effects on the climate system.

Comparing our values to daily rates reported from permafrostaffected lakes in other high-latitude areas ${ }^{5,7-9}$ suggests that our estimates for both mean daily rates of $\mathrm{CO}_{2}$ and diffusive $\mathrm{CH}_{4}$ fluxes are 1.5-14-times greater. Importantly, the $\mathrm{C}$ fluxes from WSL lakes in spring and autumn were on average 2-times greater than during summer in all permafrost zones apart from isolated permafrost zone. Such strong seasonality has been shown for other lakes and is largely explained by spring release of gas accumulated under ice in winter and autumn release of gas accumulated in hypolimnion over summer ${ }^{24-27}$. However, bottom freezing in winter ${ }^{19}$ and lack of stable thermal stratification $^{20}$ in summer of WSL lakes implies that these storage fluxes are likely not the main factors for the observed strong seasonality. Irrespectively of the underlying mechanisms, the seasonality in C fluxes from WSL lakes emphasizes the need for integrating spring and autumn $\mathrm{C}$ fluxes estimates for accurately assessing annual lake $\mathrm{C}$ emission.

Annual lake $\mathrm{C}$ emission. The total annual diffusive $\mathrm{C}$ emission $\left(\mathrm{CO}_{2}+\right.$ diffusive $\left.\mathrm{CH}_{4}\right)$ from WSL lakes shows strong differences across different permafrost zones (range: $0.1( \pm 0.1)$ to $0.3( \pm 0.1)$ $\mathrm{kg} \mathrm{C} \mathrm{m}^{-2} \mathrm{yr}^{-1}, H=22.59, P<0.05$, Fig. 3), with $2-3$ times higher lake $\mathrm{C}$ emission in the most northern zones with discontinuous and continuous permafrost compared to the southern zones with isolated and sporadic permafrost (Supplementary Table 4). Although there is a limited number of studies to compare with, the annual $\mathrm{CO}_{2}$ and diffusive $\mathrm{CH}_{4}$ emission from WSL lakes are 1.5-5-times greater than annual $\mathrm{CO}_{2}{ }^{7}$ and diffusive $\mathrm{CH}_{4}$ emission ${ }^{5}$ from other permafrost-affected lakes across the Arctic, but are similar to values reported for other thermokarst lakes in Eastern Siberia ${ }^{28}$ and Alaska ${ }^{11}$. Also, the annual diffusive $\mathrm{CH}_{4}$ emission from WSL lakes is similar to annual whole-lake $\mathrm{CH}_{4}$ ebullition from yedoma lakes ${ }^{29}$ in Eastern Siberia. 


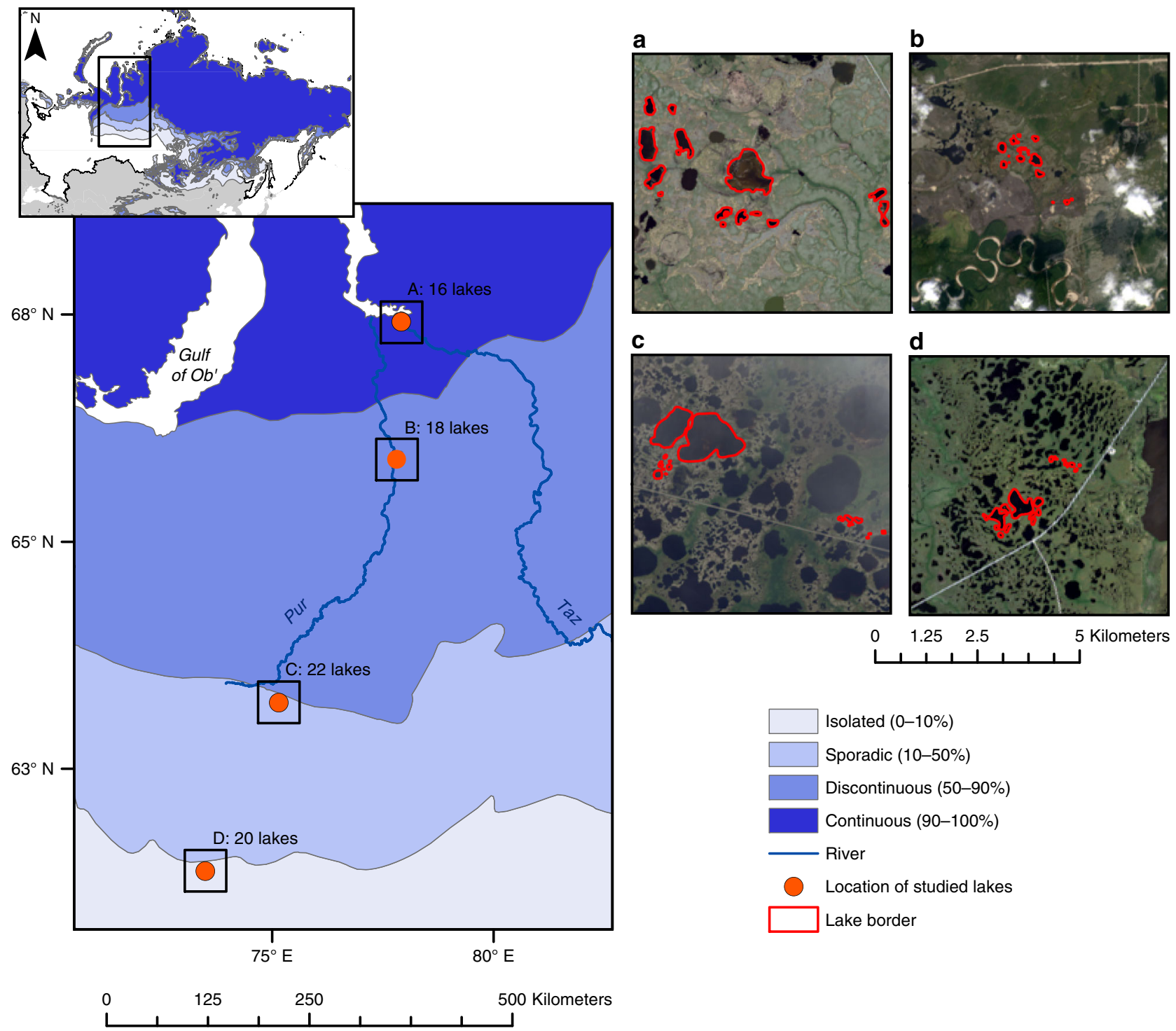

Fig. 1 Map of the study area in the Western Siberia Lowland, Russia. Blue shading represents percent permafrost extent in the area of Western Siberia Lowland based on freely-available shapefiles from Brown et al. ${ }^{58}$. Orange dots indicate the location of the studied sites and red lines show shorelines of the studied lakes. Panel (a) refers to the site in the continuous permafrost zone, panel (b) to the discontinuous, panel (c) to the sporadic permafrost zone whereas panel (d) to the isolated permafrost zone. For details on satellite images acquisition see Ancillary data

\section{Discussion}

The fact that $\mathrm{C}$ emission from WSL lakes is higher in colder permafrost-rich regions is at odds with findings from studies of boreal and arctic lakes and also the general understanding of the impact of warming on lake $\mathrm{C}$ cycling, where warming-induced OC loading and enhanced metabolism lead to increased $\mathrm{CO}_{2}$ and especially $\mathrm{CH}_{4}$ production ${ }^{2,30}$. While recent assessment of $\mathrm{C}$ emission from high-latitude lakes ${ }^{31}$ has shown a decline in $\mathrm{C}$ evasion from lakes with lower MAAT, the WSL lakes show an opposite pattern with higher $\mathrm{C}$ emission from permafrost-rich areas, where lake water temperatures are generally colder $(H=$ 51.766, $P<0.05)$. Further, there was no trend of increasing fraction of $\mathrm{CH}_{4}: \mathrm{CO}_{2}$ emission with warmer water temperatures ( $\log _{10}$-transformed, $\left.n=62, R^{2}=0.00, F_{1,60}=0.146, P>0.05\right)$. And despite the relatively high concentrations of dissolved OC in lake water $\left(15.7 \pm 7.7 \mathrm{mg} \mathrm{L}^{-1}\right)$, presumably of mainly terrestrial origin $^{19}$, there was no relationship with total lake C emission $(n$ $=73, R^{2}=0.00, F_{1,71}=1.438, P>0.05$, Supplementary Table 5). Neither did we find any dependence of total lake $C$ emission across permafrost zones of WSL to other factors (i.e., lake area, lake depth, nutrient concentrations, $\mathrm{SUVA}_{254}, \mathrm{O}_{2}$ concentration, Supplementary Table 5) that could potentially affect $\mathrm{CO}_{2}$ production and emission from lakes. Taken together, the temporal and spatial patterns in C emission of WSL lakes suggest that lake C emission is controlled differently compared to other regions, unraveling a complex interaction between climate and permafrost and their combined regulation of $\mathrm{C}$ emission from WSL lakes.

One potential explanation for the observed patterns is the delivery of $\mathrm{CO}_{2}$ from the surrounding soils, which is higher in permafrost-rich vs. permafrost-poor regions of $\mathrm{WSL}^{32}$, and is expected to result in higher $\mathrm{C}$ emission from small vs. large lakes $^{33}$. However, the lack of dependence of $\mathrm{C}$ emission on lake size suggests that variation in soil $\mathrm{CO}_{2}$ production and export alone cannot explain the observed patterns and that other factors are likely more important. A specific feature of WSL lakes compared to many other lakes in permafrost-affected regions are their shallow depths, rarely deeper than $1-1.5 \mathrm{~m}(0.8 \pm 0.7 \mathrm{~m})$, found even in lakes large in size ( $\log _{10}$-transformed, $n=74, R^{2}=0.22$, $\left.F_{1,72}=21.16, P<0.05\right)$. It is plausible that owing to the overall flat terrain of WSL (with widespread peat mounds and hollows), 

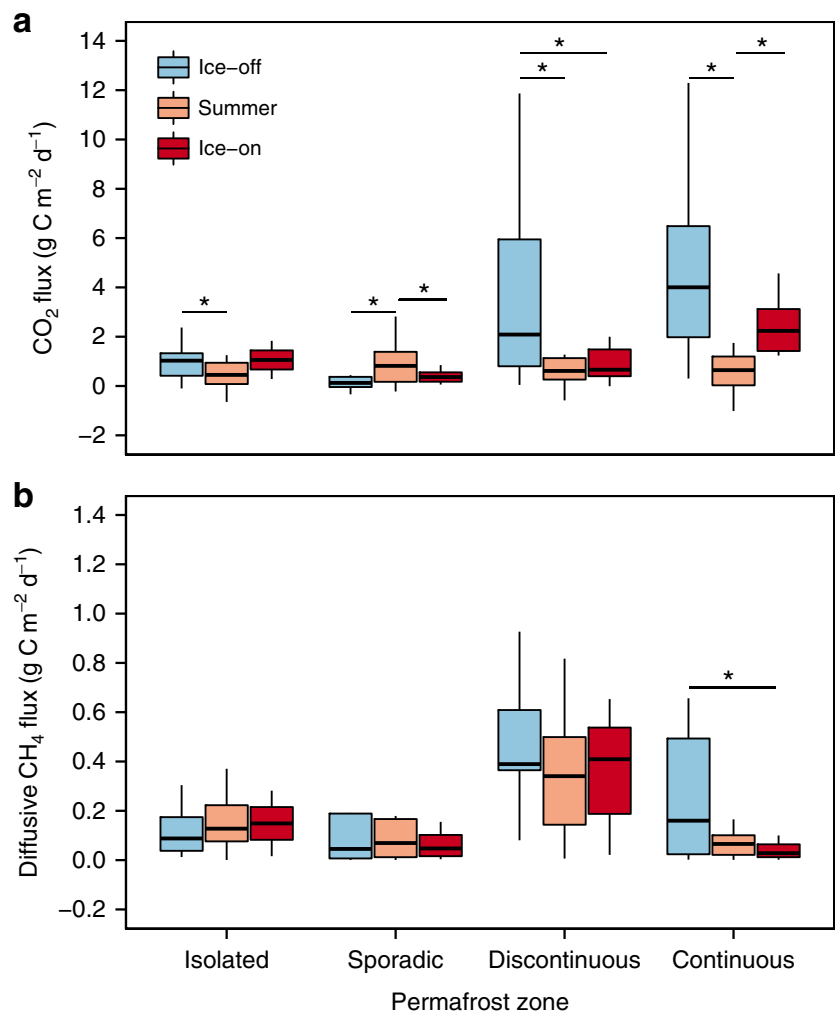

Fig. 2 Seasonal $\mathrm{CO}_{2}$ flux and diffusive $\mathrm{CH}_{4}$ flux across different permafrost zones. The panel (a) refers to $\mathrm{CO}_{2}$ flux whereas panel (b) refers to diffusive $\mathrm{CH}_{4}$ flux. Boxes are bound by 25th and 75th percentiles, whiskers show 1.5 interquartile range. Solid line represents median values while the star signifies statistically significant differences. Positive values indicate outward flux from the lakes into the atmosphere. We removed 12 outliers on panel (a) and 14 outliers on panel (b) to visually improve the graph, but used the complete dataset for statistical analyses. For sample size see Supplementary Table 1

these lakes also have relatively small catchments ${ }^{18}$. Together, this implies that sediments play a larger role in lake $\mathrm{C}$ cycling compared to deeper lakes with larger catchments where lateral inputs of $\mathrm{C}$ and its processing in the water column dominate. Shallow water depth also enhances wind-induced mixing, and thus keeps water and sediment surface warm and oxic (Supplementary Table 6), further facilitating aerobic respiration in sediments. Accordingly, published rates of net ecosystem production of $\mathrm{CO}_{2}$ in the water column of lakes and ponds within the discontinuous permafrost zone of WSL 21,34 are low $\left(\sim 0.3-0.5 \mathrm{~g} \mathrm{C} \mathrm{m}^{-2} \mathrm{~d}^{-1}\right)$ compared to $C$ fluxes $\left(1.7 \pm 1.7 \mathrm{~g} \mathrm{C} \mathrm{m}^{-2} \mathrm{~d}^{-1}\right)$ measured in this study. The sediments are mainly composed of organic detritus from flooded peat bogs and it has been shown that a major part of this peat is mineralized in sediments of WSL lakes ${ }^{35}$ over the course of lake development. Thus, if sediments play an important role in lake $\mathrm{C}$ cycling it is also likely that observed latitudinal patterns in $\mathrm{C}$ emission are largely governed by a higher availability of $\mathrm{OC}$ for mineralization of recently thawed lake sediments in the north compared to in the south, similar to what has been reported for availability of thawed soil OC for mineralization in lake ${ }^{2}$ and river water ${ }^{4,36,37}$. Also, given the shallow nature of these lakes, photosynthetic $\mathrm{CO}_{2}$ fixation is likely predominately benthic and mainly constrained by light conditions ${ }^{38}$ thus decreasing with the shorter ice-free season in the north compared to the south. Another potential mechanism is variability in photomineralization, but recent studies suggest photomineralization to be negligible for the net OC mineralization in permafrost-affected lakes

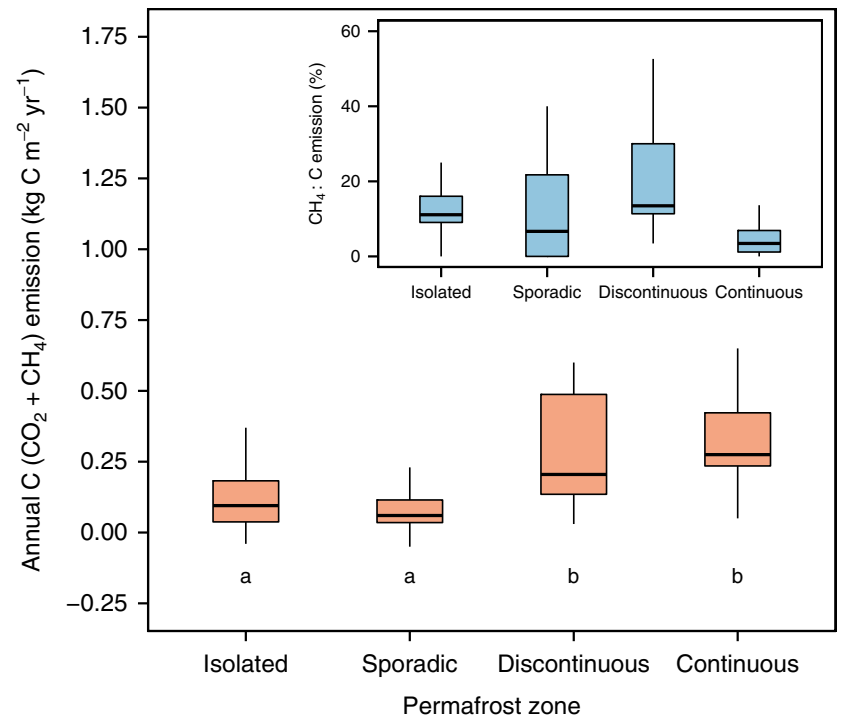

Fig. 3 Annual $\mathrm{C}\left(\mathrm{CO}_{2}+\right.$ diffusive $\left.\mathrm{CH}_{4}\right)$ emission across different permafrost zones. Annual $\mathrm{C}$ emission is greater in colder permafrost-rich regions compared to warmer permafrost-poor regions (see Fig. 1 for the geographical location of different permafrost zones). The inset shows the percent of diffusive $\mathrm{CH}_{4}$ emission in annual $\mathrm{C}$ emission across different permafrost zones. Boxes are bound by 25 th and 75 th percentiles, whiskers show 1.5 interquartile range. Solid line represents median values. Positive values indicate outward flux from the lakes into the atmosphere.

Permafrost zones that share a letter are not significantly different. We removed 3 outliers on the main plot and 5 outliers on the inset to visually improve the graph, but used the complete dataset for statistical analyses. For sample size see Supplementary Table 4

located in this area ${ }^{39}$. Nevertheless, the relative importance of greenhouse gas sources and sinks in WSL lakes remains a knowledge gap and more in-depth studies are needed to infer a better mechanistic understanding of controls of WSL lake C evasion.

Up-scaling our results to the permafrost-affected area of WSL $\left(60-74^{\circ} \mathrm{N}, \sim 1.3\right.$ million $\left.\mathrm{km}^{2}\right)$ shows that WSL lakes at present emit $\sim 12 \pm 2.6 \mathrm{Tg} \mathrm{C} \mathrm{yr}^{-1}$. The $\mathrm{C}$ emission from WSL lakes alone is half of the $\mathrm{C}$ emission from lakes reported earlier for the Artic region between 63 and $90^{\circ} \mathrm{N}^{31}$, and 2-times greater than annual river OC export ${ }^{40-42}$ from WSL to the Arctic Ocean. Although these estimates contain uncertainties, the $\mathrm{C}$ emission is 3-times greater than total $\mathrm{CH}_{4}$ emission from yedoma lakes in Eastern Siberia ${ }^{29}$ suggesting that thermokarst lakes of WSL are important contributors to net $\mathrm{C}$ evasion from high latitude lakes and that previous assessment of northern lake $\mathrm{C}$ emission $^{31}$ is likely underestimated. In our up-scaling we assumed a lake coverage of $6 \%{ }^{16,17}$, yet recent estimates of certain areas within WSL suggest that wet area extent (flood zones + lakes) can have a strong temporal variation and reach up to $\sim 70 \%{ }^{43}$ during spring and autumn. This implies that WSL lake $\mathrm{C}$ emission is likely higher than our conservative estimate, further emphasizing the need to capture variability in both flux rates and thermokarst lake area across the Arctic.

Our results stress the need to integrate lake $\mathrm{C}$ emission estimates to accurately predict permafrost feedback to a warming climate. Given the vast terrestrial stock of WSL $(\sim 70 \mathrm{Pg} \mathrm{C})^{13,14}$, even a minor change in lateral OC export is likely to considerably alter C emission from WSL lakes. Further warming will result in a northward shift of permafrost zones ${ }^{44}$ and their subsequent replacement with permafrost-free regions. Interestingly, by substituting space-for-time our results suggest that this would lead to 
a decrease in C emission from WSL lakes. However, such spacefor-time substitution approach is likely unable to fully capture impacts of new environmental conditions following warming and permafrost thaw on lake $\mathrm{C}$ cycling. We therefore conclude that understanding this complex interaction between climate and permafrost, especially in such areas as WSL, is fundamental when predicting future $\mathrm{C}$ cycle and call for more work and alternative approaches to test such predictive models.

\section{Methods}

Sampling sites. The studied region is the Western Siberia Lowland (WSL, Russia). WSL has a humid semi-continental climate ${ }^{17}$ with MAAT ranging from ca. $-0.5^{\circ} \mathrm{C}$ in the south to $-9.5^{\circ} \mathrm{C}$ in the north, and mean annual precipitation ranging from 600 to $350 \mathrm{~mm} \mathrm{yr}^{-1}$, accordingly ${ }^{42,45}$. The region is characterized by a low and flat relief $(0-200 \text { masl })^{46}$ and is dominated by Pliocene sands and clays ${ }^{42}$. The combination of both cold temperatures and flat relief have enabled accumulation of $\sim 70 \mathrm{Pg}$ of carbon in region's extensive peatlands over past 11,000 years $^{13,14}$. More than half of the region is influenced by permafrost, with $15 \%$ of WSL covered with continuous and $39 \%$ covered with discontinuous, sporadic, and isolated permafrost ${ }^{13,47}$. We sampled 76 lakes of different size across permafrost gradient of WSL (between $62^{\circ} \mathrm{N}$ and $67^{\circ} \mathrm{N}$ ) (Fig. 1), with 20 lakes located in the isolated zone, 22 in sporadic, 18 in discontinuous, and 16 in continuous, respectively. The size of the sampled lakes ranged from 115 to $1,237,000 \mathrm{~m}^{2}$. We visited all sites in 2016 at ice-off event (20th of May-13th of June), in the middle of the summer (9th-24th of August) and just before lakes established ice cover (26th of September-8th of October). We designed our three sampling campaigns in a way that they followed the natural propagation of seasons across WSL, by starting the spring sampling campaign from the south, whereas summer and autumn campaigns from the north.

Sampling procedure. Sampling of surface water was carried out from a boat at the deepest part of lakes in lakes smaller than $10,000 \mathrm{~m}^{2}$, while samples from lakes larger than $10,000 \mathrm{~m}^{2}$ were taken $\sim 200-300 \mathrm{~m}$ offshore. At each location we measured water temperature and dissolved oxygen saturation (YSI ProODO Handheld Optical Dissolved Oxygen meter), $\mathrm{pH}$ and specific conductivity (WTW Multi 3320 multiparameter) as well as water depth (Cole-Parmer), air temperature, and atmospheric pressure (Silva). Dissolved oxygen saturation was measured by submerging the probe at $50 \mathrm{~cm}$ interval until reaching lake sediment interface. Water samples for DOC, DIC, nutrients, and dissolved $\mathrm{CH}_{4}$ were collected and analyzed following methods described elsewhere ${ }^{18,19,48}$. Sampling for partial pressure of $\mathrm{CO}_{2}\left(p \mathrm{CO}_{2}\right)$ in situ was conducted following the procedure described in our previous work ${ }^{48}$. We also measured ultraviolet absorbance at $245 \mathrm{~nm}\left(\mathrm{UV}_{245}\right)$ (Bruker CARY-50 UV-VIS) and calculated specific ultraviolet absorbance $\left(\mathrm{SUVA}_{254}\right)$ of the sampled water following conversion of $\mathrm{UV}_{245}$ to $\mathrm{UV}_{254}{ }^{49}$.

\section{C fluxes calculations. $\mathrm{CO}_{2}$ fluxes were measured with small lightweight ${ }^{50}$} $(\sim 30-32 \mathrm{~cm}$ in diameter, $\sim 270-300 \mathrm{~g})$ floating chambers ${ }^{50,51}$ equipped with nondispersive infrared $\mathrm{CO}_{2}$ logger (ELG, SenseAir) and calculated following methods described in literature $48,51,52$. We calibrated $\mathrm{CO}_{2}$ loggers in the lab against pure $\mathrm{N}_{2}$ before each sampling campaign. We placed 2-6 chambers per lake along the transects from the shore to the center of the lake, if the lake size allowed. If the lake was sufficiently big to prevent us from reaching its center, we distributed the chambers along the transects from the shore to approximately 100-200 m offshore. The $\mathrm{CO}_{2}$ accumulation rate inside each chamber was recorded continuously at 300 $\mathrm{s}$ interval. We used first 1-2.5 h of measurements for computing $\mathrm{CO}_{2}$ accumulation rate inside each chamber by linear regression. Although $87 \%$ of 487 measurements had a linear increase with $R^{2} \geq 0.76,13 \%$ of the measurements had a linear increase with $R^{2} \leq 0.75$. These measurements were retained only if the average $R^{2}$ between the replicates was greater or equal to 0.55 , discarding those measurements that did not meet this requirement. Also, while $71 \%$ of all chamber readings across all seasons had linear increase, $29 \%$ of measurements recorded a persistent decrease in $\mathrm{CO}_{2}$ accumulation rate. We interpreted these measurements as $\mathrm{CO}_{2}$ uptake and retained the values if $p \mathrm{CO}_{2}$ concentration in the water of the respective lake was close to or below atmospheric equilibrium set to $404.2 \mathrm{ppm}^{48,51,52}$, mean annual $p \mathrm{CO}_{2}$ concentration in the air for 2016 (Mauna Loa Observatory fttp://aftp.cmdl. noaa.gov/products/trends/co2/co2_annmean_mlo.txt). We calculated instantaneous diffusive $\mathrm{CH}_{4}$ fluxes using concentrations of dissolved $\mathrm{CH}_{4}$ in the water and air-water equilibrium $p \mathrm{CH}_{4}$ concentration of $1.8 \mathrm{ppm}$, mean annual $p \mathrm{CH}_{4}$ concentration in the air for 2016 (Mauna Loa Observatory fttp://aftp.cmdl.noaa.gov/ products/trends/ch4/ch4_annmean_gl.txt). We further averaged both $\mathrm{CO}_{2}$ and diffusive $\mathrm{CH}_{4}$ fluxes from all chambers for each of the lakes and summed them up to estimate total $\mathrm{C}$ fluxes from the respective lakes.

Chamber $\mathbf{C}$ fluxes vs. wind-based model $\mathbf{C}$ fluxes. Although chamber measurements can potentially increase $\mathrm{C}$ fluxes due to turbulence at chambers' edge $\mathrm{e}^{53}$, they are still the most accurate tool for obtaining direct flux measurements ${ }^{50}$ in such remote locations as Western Siberia. To compare our results obtained with chambers with wind-based models we computed $\mathrm{C}$ fluxes using published relationship from Cole and Caraco ${ }^{54}$ (Eq. (1)) and Vachon and Prairie ${ }^{55}$ (Eq. (2)):

$$
\begin{gathered}
k_{600}=2.07+0.215 \cdot U_{10}^{1.7} \\
k_{600}=2.51( \pm 0.99)+1.48( \pm 0.34) \cdot U_{10}+0.39( \pm 0.08) \cdot U_{10} \cdot \log _{10} \mathrm{LA}
\end{gathered}
$$

where $U_{10}$ is the wind speed at $10 \mathrm{~m}$ height (monthly average) and LA is lake area in $\mathrm{km}^{2}$. We used mean wind speed recorded at the nearest meteostation during the time the chambers were deployed at each of our sites, while we used the lake area representing the conditions of summer sampling (for details see Ancillary data). The results suggest a relationship between measured and modeled fluxes, but also show that fluxes calculated with wind-based models are on average 3 and 4-times lower than measured $\mathrm{CO}_{2}$ and $\mathrm{CH}_{4}$ fluxes, respectively (Supplementary Figure 1). This discrepancy between modeled and measured values may be explained by the remoteness of the studied lakes in relation to the respective meteostations $(\sim 20-70$ $\mathrm{km}$ from the lakes), and points out the need for future studies relying on windbased models for WSL lakes to validate these findings with more precise local wind data.

Ancillary data. We quantified average wind speed, mean annual temperature, and precipitation for 2016 at each of the studied sites based on meteorological records available at https://rp5.ru/. Since we followed our sampled lakes from ice-off event until the establishment of ice cover, we used the number of ice-off days from our field observations. We quantified water surface area of the respective lakes by analyzing satellite images of the studied sites. We used Landsat 8 scenes freelyavailable at https://remotepixel.ca/projects/satellitesearch.html. Due to the substantial cloud cover $(>50 \%)$ of the images matching our ice-on and ice-off sampling campaigns, we used four images for 19th of June and 14th of July

(LC81570132016171LGN00_B432, LC81560142016196LGN00_B432,

LC81560152016196LGN00_B432, LC81570162016171LGN00_B432) that had cloud cover within $10-30 \%$ and reflected the conditions of summer sampling. We calculated water surface areas of each of the studied lakes by manually drawing polygons around each lake within the studied sites using ArcMap 10.5. If the lakes were not visible on the Landsat 8 scene, we first drew the polygon of the respective lake in Google Earth, quantified its area and then drew a polygon of similar size in the Landsat 8 scene at the location matching lake's GPS coordinates. We further checked our lake water surface areas against water surface areas of GLOWABO global lake database ${ }^{56}$, where information for 16 out of 76 lakes sampled in this study is available. Our quantified lake water surface areas were in good agreement with those reported in GLOWABO ( $\log _{10}$-transformed, $n=16, R^{2}=0.94, F_{1,14}=$ 247.9, $P<0.05$ )

Upscaling. We estimated present lake $\mathrm{C}$ emission from the permafrost-affected area of WSL ${ }^{16,17}\left(60-74^{\circ} \mathrm{N}\right)$ by multiplying total lake area of $6 \%{ }^{16,17}$ with mean lake $\mathrm{C}$ emission measured in our study. We assumed $15 \%$ uncertainty in estimates of both total lake area and lake $\mathrm{C}$ emission and propagated our error following equation:

$$
\delta R=|R| \sqrt{\left(\frac{\delta x}{x}\right)^{2}+\left(\frac{\delta y}{y}\right)^{2}}
$$

where $\delta R$ is the uncertainty, $R$ is a result of multiplication of total lake area with mean lake $\mathrm{C}$ emission, while $\delta x$ and $\delta y$ are $15 \%$ uncertainty estimates for total lake area, $x$, and mean lake $\mathrm{C}$ emission, $y$, respectively. We further estimated present $\mathrm{C}$ emission from WSL lakes based on lake coverage available in literature ${ }^{56,57}$ and compiled different estimates in Supplementary Table 7.

Statistical analysis. All statistical analyses and calculations were performed in RStudio statistical software (Version 1.0.44, RStudio, Inc., 〈www.r-project.org )) Prior to statistical analyses, we grouped sampled lakes based on the sampling location in four groups representing different permafrost zones: isolated $\left(62^{\circ} \mathrm{N}, n\right.$ $=20)$, sporadic $\left(63^{\circ} \mathrm{N}, n=22\right)$, discontinuous $\left(66^{\circ} \mathrm{N}, n=18\right)$, and continuous $\left(67^{\circ}\right.$ $\mathrm{N}, n=16$ ). We further assessed homogeneity of variances between the groups by using either parametric Bartlett and non-parametric Fligner-Killeen tests, or by randomly subsampling 10 lakes within each permafrost zone to balance our study design. If the variances between the groups were homogenous and the data was normally distributed, we used one-way analysis of variance (ANOVA) with Tukey's HSD post-hoc comparisons to investigate differences in annual $\mathrm{C}$ emission and mean summer concentrations of variables among different permafrost zones. If the variances between the groups were not homogeneous, we used a non-parametric alternative of Kruskal-Wallis test together with Pairwise Wilcox test (Holm adjustment).

When analyzing the seasonal differences in variables among different permafrost zones, we classified sampled lakes in four different classes based on water surface area: thaw ponds $\left(<499 \mathrm{~m}^{2}, n=24\right)$, thermokarst lakes (500-9999 $\left.\mathrm{m}^{2}, n=90\right)$, mature lakes $\left(10,000-999,999 \mathrm{~m}^{2}, n=90\right)$ and massive lakes $\left(>999,999 \mathrm{~m}^{2}, n=3\right)$. We further classified sampled lakes in five categories based on average water depth in different seasons: very shallow $(<0.4 \mathrm{~m}, n=38)$, shallow $(0.5-0.9 \mathrm{~m}, n=69)$, average $(1-1.4 \mathrm{~m}, n=46)$, deep (1.5-1.9 $\mathrm{m}, n=14)$, and very 
deep ( $>1.9 \mathrm{~m}, n=15)$. We used linear mixed effects models (lme4 package) when analyzing two-way interactions of seasons and permafrost zones on the transformed per unit area daily $\mathrm{CO}_{2}$ fluxes, diffusive $\mathrm{CH}_{4}$ fluxes, surface water $p \mathrm{CO}_{2}$ and dissolved $\mathrm{CH}_{4}$ concentrations (Supplementary Tables 2-3, 8-10) along with other water chemistry variables. We used permafrost zones and seasons as fixed factors that are expected to have a systematic influence on the data while we allowed our sampled lakes to randomly vary inside permafrost zone groups, lake size classes and water depth categories as well as seasons inside permafrost zone groups to correct for possible effect of lake size and depth on the respective variable concentrations. In that way, we assumed that whatever the effects of permafrost extent and seasons are, they are going to be the same for all lakes sampled within each permafrost zone group. The best model fit was selected based on Akaike Information Criterion (AIC). We also performed contrasts analyses on the respective mixed effects models by constructing orthogonal contrasts to compare seasons between each other and avoid multiple comparisons (package lsmeans).

We further used simple linear regression when analyzing the relationship between variables of interest. Note that we report untransformed data in the text, figures, and tables. Because of non-normal distribution of the data, we use mean \pm IQR when reporting uncertainty. All statistical tests used a significance level of $5 \%$ $(\alpha=0.05)$ and were run on the complete dataset.

\section{Data availability}

All data generated and analyzed during this study are included in this published article (and its Supplementary Data 1-2).

\section{Code availability}

Computer code for data analyses is available upon request.

Received: 6 September 2018 Accepted: 20 March 2019

Published online: 04 April 2019

\section{References}

1. Schuur, E. A. G. et al. Climate change and the permafrost carbon feedback. Nature 520, 171-179 (2015).

2. Vonk, J. E. et al. Reviews and syntheses: effects of permafrost thaw on Arctic aquatic ecosystems. Biogeosciences 12, 7129-7167 (2015).

3. Olefeldt, D. et al. Circumpolar distribution and carbon storage of thermokarst landscapes. Nat. Commun. 7, 13043 (2016).

4. Vonk, J. E. et al. High biolability of ancient permafrost carbon upon thaw. Geophys. Res. Lett. 40, 2689-2693 (2013).

5. Wik, M., Varner, R. K., Anthony, K. W., MacIntyre, S. \& Bastviken, D. Climate-sensitive northern lakes and ponds are critical components of methane release. Nat. Geosci. 9, 99-105 (2016).

6. Cole, J. J., Caraco, N. F., Kling, G. W. \& Kratz, T. K. Carbon dioxide supersaturation in the surface waters of lakes. Science 265, 1568-1570 (1994).

7. Laurion, I. et al. Variability in greenhouse gas emissions from permafrost thaw ponds. Limnol. Oceanogr. 55, 115-133 (2010).

8. Lundin, E. J., Giesler, R., Persson, A., Thompson, M. S. \& Karlsson, J. Integrating carbon emissions from lakes and streams in a subarctic catchment. J. Geophys. Res. Biogeosci. 118, 1200-1207 (2013).

9. Elder, C. D. et al. Greenhouse gas emissions from diverse Arctic Alaskan lakes are dominated by young carbon. Nat. Clim. Change 8, 166-171 (2018).

10. Matveev, A., Laurion, I., Deshpande, B. N., Bhiry, N. \& Vincent, W. F. High methane emissions from thermokarst lakes in subarctic peatlands. Limnol. Oceanogr. 61, S150-S164 (2016)

11. Sepulveda-Jauregui, A., Walter Anthony, K. M., Martinez-Cruz, K., Greene, S. \& Thalasso, F. Methane and carbon dioxide emissions from 40 lakes along a north-south latitudinal transect in Alaska. Biogeosciences 12, 3197-3223 (2015).

12. Cole, J. J. et al. Plumbing the global carbon cycle: integrating inland waters into the terrestrial carbon budget. Ecosystems 10, 172-185 (2007).

13. Frey, K. E., Siegel, D. I. \& Smith, L. C. Geochemistry of west Siberian streams and their potential response to permafrost degradation. Water Resour. Res. 43 (2007).

14. Sheng, Y. et al. A high-resolution GIS-based inventory of the west Siberian peat carbon pool. Glob. Biogeochem. Cycles 18 (2004).

15. Romanovsky, V. E. et al. Thermal state of permafrost in Russia. Permafr. Periglac. Process. 21, 136-155 (2010).

16. Polishchuk, Y. et al. Size distribution, surface coverage, water, carbon, and metal storage of thermokarst lakes in the permafrost zone of the Western Siberia Lowland. Water 9, 228 (2017).

17. Polishchuk, Y. M. et al. Minor contribution of small thaw ponds to the pools of carbon and methane in the inland waters of the permafrost-affected part of the Western Siberian Lowland. Environ. Res. Lett. 13, 045002 (2018).
18. Manasypov, R. M., Pokrovsky, O. S., Kirpotin, S. N. \& Shirokova, L. S. Thermokarst lake waters across the permafrost zones of western Siberia. Cryosphere 8, 1177-1193 (2014).

19. Manasypov, R. M. et al. Seasonal dynamics of organic carbon and metals in thermokarst lakes from the discontinuous permafrost zone of western Siberia. Biogeosciences 12, 3009-3028 (2015).

20. Pokrovsky, O. S., Shirokova, L. S., Kirpotin, S. N., Kulizhsky, S. P. \& Vorobiev, S. N. Impact of western Siberia heat wave 2012 on greenhouse gases and trace metal concentration in thaw lakes of discontinuous permafrost zone. Biogeosciences 10, 5349-5365 (2013).

21. Shirokova, L. S. et al. Biogeochemistry of organic carbon, $\mathrm{CO}_{2}, \mathrm{CH}_{4}$, and trace elements in thermokarst water bodies in discontinuous permafrost zones of Western Siberia. Biogeochemistry 113, 573-593 (2013).

22. Sabrekov, A. F. et al. Variability in methane emissions from West Siberia's shallow boreal lakes on a regional scale and its environmental controls. Biogeosciences 14, 3715-3742 (2017).

23. Walter Anthony, K. et al. 21st-century modeled permafrost carbon emissions accelerated by abrupt thaw beneath lakes. Nat. Commun. 9, 3262 (2018).

24. Karlsson, J., Giesler, R., Persson, J. \& Lundin, E. High emission of carbon dioxide and methane during ice thaw in high latitude lakes. Geophys. Res. Lett. 40, 1123-1127 (2013).

25. Karlsson, J. M., Lyon, S. W. \& Destouni, G. Temporal behavior of lake sizedistribution in a thawing permafrost landscape in northwestern Siberia. Remote Sens. 6, 621-636 (2013).

26. Karlsson, J. et al. Quantifying the relative importance of lake emissions in the carbon budget of a subarctic catchment. J. Geophys. Res. 115, G03006 (2010).

27. Michmerhuizen, C. M., Striegl, R. G. \& McDonald, M. E. Potential methane emission from north-temperate lakes following ice melt. Limnol. Oceanogr. 41, 985-991 (1996)

28. Zimov, S. A. North Siberian lakes: a methane source fueled by pleistocene carbon. Science 277, 800-802 (1997).

29. Walter, K. M., Zimov, S. A., Chanton, J. P., Verbyla, D. \& Chapin, F. S. Methane bubbling from Siberian thaw lakes as a positive feedback to climate warming. Nature 443, 71-75 (2006).

30. Yvon-Durocher, G. et al. Methane fluxes show consistent temperature dependence across microbial to ecosystem scales. Nature 507, 488-491 (2014).

31. Lundin, E. J. et al. Large difference in carbon emission-burial balances between boreal and arctic lakes. Sci. Rep. 5, 14248 (2015).

32. Raudina, T. V. et al. Permafrost thaw and climate warming may decrease the $\mathrm{CO}_{2}$, carbon, and metal concentration in peat soil waters of the Western Siberia Lowland. Sci. Total Environ. 634, 1004-1023 (2018).

33. Rocher-Ros, G. et al. Large lakes dominate $\mathrm{CO}_{2}$ evasion from lakes in an Arctic catchment. Geophys. Res. Lett. 44, 12, 254-12, 261 (2017).

34. Shirokova, L. S., Pokrovsky, O. S., Kirpotin, S. N. \& Dupré, B. Heterotrophic bacterio-plankton in thawed lakes of the northern part of Western Siberia controls the $\mathrm{CO}_{2}$ flux to the atmosphere. Int. J. Environ. Stud. 66, 433-445 (2009).

35. Audry, S., Pokrovsky, O. S., Shirokova, L. S., Kirpotin, S. N. \& Dupré, B. Organic matter mineralization and trace element post-depositional redistribution in Western Siberia thermokarst lake sediments. Biogeosciences 8, 3341-3358 (2011).

36. Vonk, J. E. et al. Biodegradability of dissolved organic carbon in permafrost soils and aquatic systems: a meta-analysis. Biogeosciences 12, 6915-6930 (2015).

37. Abbott, B. W., Larouche, J. R., Jones, J. B., Bowden, W. B. \& Balser, A. W. Elevated dissolved organic carbon biodegradability from thawing and collapsing permafrost. J. Geophys. Res. Biogeosci. 119, 2049-2063 (2014).

38. Ask, J., Karlsson, J. \& Jansson, M. Net ecosystem production in clear-water and brown-water lakes. Glob. Biogeochem. Cycles 26, GB1017 (2012).

39. Shirokova, L. S. et al. Humic surface waters of frozen peat bogs (permafrost zone) are highly resistant to bio- and photodegradation. Biogeosci. Discuss. https://doi.org/10.5194/bg-2018-528 (2019).

40. Cooper, L. W. et al. Flow-weighted values of runoff tracers $(\delta 18 \mathrm{O}, \mathrm{DOC}, \mathrm{Ba}$, alkalinity) from the six largest Arctic rivers. Geophys. Res. Lett. 35, 3-7 (2008).

41. Gordeev, V. V., Martin, J. M., Sidorov, I. S. \& Sidorova, M. V. A reassessment of the Eurasian river input of water, sediment, major elements, and nutrients to the Arctic Ocean. Am. J. Sci. 296, 664-691 (1996).

42. Pokrovsky, O. S. et al. Permafrost coverage, watershed area and season control of dissolved carbon and major elements in western Siberian rivers. Biogeosciences 12, 6301-6320 (2015).

43. Zakharova, E., Kouraev, A. V., Rémy, F., Zemtsov, V. \& Kirpotin, S. N. Seasonal variability of the Western Siberia wetlands from satellite radar altimetry. J. Hydrol. 512, 366-378 (2014).

44. Chadburn, S. E. et al. An observation-based constraint on permafrost loss as a function of global warming. Nat. Clim. Change 7, 1-6 (2017).

45. Vorobyev, S. et al. Permafrost boundary shift in Western Siberia may not modify dissolved nutrient concentrations in rivers. Water $\mathbf{9 ,}, 985$ (2017). 
46. Karlsson, J. M., Lyon, S. W. \& Destouni, G. Thermokarst lake, hydrological flow and water balance indicators of permafrost change in Western Siberia. $J$. Hydrol. 464-465, 459-466 (2012).

47. Frey, K. E. \& McClelland, J. W. Impacts of permafrost degradation on arctic river biogeochemistry. Hydrol. Process. 23, 169-182 (2009).

48. Serikova, S. et al. High riverine $\mathrm{CO}_{2}$ emissions at the permafrost boundary of Western Siberia. Nat. Geosci. 11, 825-829 (2018).

49. Cuthbert, I. D. \& del Giorgio, P. Toward a standard method of measuring color in freshwater. Limnol. Oceanogr. 37, 1319-1326 (1992).

50. Bastviken, D., Sundgren, I., Natchimuthu, S., Reyier, H. \& Gålfalk, M Technical note: cost-efficient approaches to measure carbon dioxide $\left(\mathrm{CO}_{2}\right)$ fluxes and concentrations in terrestrial and aquatic environments using mini loggers. Biogeosciences 12, 3849-3859 (2015).

51. Alin, S. R. et al. Physical controls on carbon dioxide transfer velocity and flux in low-gradient river systems and implications for regional carbon budgets. J. Geophys. Res. 116, G01009 (2011).

52. Vachon, D., Prairie, Y. T. \& Cole, J. J. The relationship between near-surface turbulence and gas transfer velocity in freshwater systems and its implications for floating chamber measurements of gas exchange. Limnol. Oceanogr. 55, 1723-1732 (2010).

53. Lorke, A. et al. Technical note: drifting versus anchored flux chambers for measuring greenhouse gas emissions from running waters. Biogeosciences 12, 7013-7024 (2015).

54. Cole, J. J. \& Caraco, N. F. Atmospheric exchange of carbon dioxide in a lowwind oligotrophic lake measured by the addition of SF 6. Limnol. Oceanogr. 43, 647-656 (1998).

55. Vachon, D. \& Prairie, Y. T. The ecosystem size and shape dependence of gas transfer velocity versus wind speed relationships in lakes. Can. J. Fish. Aquat. Sci. 70, 1757-1764 (2013).

56. Verpoorter, C., Kutser, T., Seekell, D. A. \& Tranvik, L. J. A global inventory of lakes based on high-resolution satellite imagery. Geophys. Res. Lett. 41, 6396-6402 (2014).

57. Messager, M. L., Lehner, B., Grill, G., Nedeva, I. \& Schmitt, O. Estimating the volume and age of water stored in global lakes using a geo-statistical approach. Nat. Commun. 7, 13603 (2016).

58. Brown, J., Ferrians, O. J. Jr., Heginbottom, J. A. \& Melnikov, E. S. CircumArctic Map of Permafrost and Ground Ice Conditions (2001).

\section{Acknowledgements}

The study was a part of JPI Climate initiative, financially supported by VR (the Swedish Research Council), Grant no. 325-2014-6898. Additional funding from the RNF (RSCF),
Grant no. 17-77-10067, to R.M.M. is acknowledged. The authors thank Blaize Denfeld for advice on data analysis.

\section{Author contributions}

J.K., O.S.P. and S.S. designed the study. S.S., I.V.K., A.G.L., R.M.M. and O.S.P. contributed to sampling and chemical analyses. S.S. analyzed data, prepared figures and tables. S.S. wrote the paper with contribution from J.K. and O.S.P. All authors commented on the manuscript.

\section{Additional information}

Supplementary Information accompanies this paper at https://doi.org/10.1038/s41467019-09592-1.

Competing interests: The authors declare no competing interests.

Reprints and permission information is available online at http://npg.nature.com/ reprintsandpermissions/

Journal peer review information: Nature Communications thanks Armando SepulvedaJauregui and the other anonymous reviewers for their contribution to the peer review of this work.

Publisher's note: Springer Nature remains neutral with regard to jurisdictional claims in published maps and institutional affiliations.

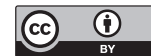

Open Access This article is licensed under a Creative Commons Attribution 4.0 International License, which permits use, sharing, adaptation, distribution and reproduction in any medium or format, as long as you give appropriate credit to the original author(s) and the source, provide a link to the Creative Commons license, and indicate if changes were made. The images or other third party material in this article are included in the article's Creative Commons license, unless indicated otherwise in a credit line to the material. If material is not included in the article's Creative Commons license and your intended use is not permitted by statutory regulation or exceeds the permitted use, you will need to obtain permission directly from the copyright holder. To view a copy of this license, visit http://creativecommons.org/ licenses/by/4.0/.

(C) The Author(s) 2019 